\title{
PENGEMBANGAN SISTEM INFORMASI EKSEKUTIF AKADEMIK UNTUK MEMBANTU PENGAMBILAN KEPUTUSAN
}

\author{
Ely Nuryani ${ }^{1}$ \\ ${ }^{I}$ Dosen Fakultas Ilmu Komputer Universitas Banten Jaya \\ Jl. Ciwaru Raya No. 2, Kota Serang - Banten \\ Email:elynuryanie@yahoo.com
}

\begin{abstract}
ABSTRAK
Pimpinan terlibat dalam perencanaan strategis dan merupakan pengambil keputusan dalam suatu organisasi maka pimpinan memiliki pengaruh yang sangat besar terhadap kinerja suatu organisasi yang dipimpinnya. Demi menunjang kinerjanya sebagai pengambil keputusan, pimpinan membutuhkan informasi yang cepat, tepat dan akurat. Selama ini pimpinan di Universitas Banten Jaya bekerja tanpa bantuan suatu sistem sehingga dalam memperoleh informasi membutuhkan waktu lama dan proses yang rumit sehingga dirasa cukup sulit bagi pimpinan. Untuk memenuhi kebutuhan pimpinan di Universitas Banten Jaya tersebut, maka dilakukan pengembangan sistem informasi eksekutif akademik. Sistem ini dirancang untuk dapat diakses dengan mudah, menyediakan informasi akademik yang akurat, relevan dan tepat waktu. Pengembangan sistem menggunakan metode waterfall dengan unified modeling language (UML) sebagai media pemodelannya. Pemrograman berbasis web dipilih sebagai bahasa pemrograman dalam pengembangan sistem ini dilengkapi dengan dashboard dan smart filtering untuk mempermudah pimpinan dalam memperoleh dan memahami informasi. Otoritas diberikan kepada pimpinan dalam bentuk user account dan password sebagai media bagi pimpinan agar dapat mengakses sistem dengan mudah, kapan dan dimana saja. Hasilnya sistem informasi eksekutif akademik berhasil membantu pimpinan dalam memperoleh informasi akademik dengan mudah, dan membantu dalam pengambilan keputusan.
\end{abstract}

Kata kunci: akademik, pimpinan, sistem informasi eksekutif.

\begin{abstract}
Leaders are involved in strategic planning and the decision-makers in an organization that's why leaders have an enormous influence on the performance of an organization that they lead. To support their performance as decision-makers, leaders need fast, precise, and accurate information. During this time, leaders of Banten Jaya University work without help and support of a system so to gain information, it takes a long and complicated process that it feels quite hard for the leaders. To fulfill the needs of leaders in Banten Jaya University, then do development of executive information systems of academic. This system is designed to be easily accessible, providing academic information that is accurate, relevant and timely. System development is using the waterfall method with unified modeling language (UML) as a modeling media. Webbased programming selected as the programming language in the development of this system which equipped with a dashboard and smart filtering to facilitate leaders in obtaining and understanding information. Authority is given to the leaders in the form of user account and password as a media for the leaders in order to access the system easily, anytime and anywhere. The result is an executive information system of academic success helps leaders gain academic information easily, and assist in decision making.
\end{abstract}

Keywords: academic, executive information system, leaders.

Vol.3 No.2 - Agustus 2017 


\section{PENDAHULUAN}

Informasi merupakan kebutuhan utama bagi sebuah lembaga pendidikan terutama pendidikan tinggi. Informasi terutama dibutuhkan oleh para pimpinan perguruan tinggi yang dapat menentukan keberhasilan dalam pengelolaan perguruan tinggi. Hal tersebut dikarenakan pihak pimpinan perguruan tinggi terlibat dalam perencanaan strategis dan penetapan kebijakan perguruan tinggi yang akan sangat berpengaruh terhadap kinerja perguruan tinggi. Ketidakakuratan informasi yang tersedia, tidak relevannya informasi yang diberikan, dan lambatnya informasi yang diterima dapat menjadi penyebab pimpinan perguruan tinggi tidak tepat bahkan salah dalam pengambilan keputusan. Pada akhirnya, kinerja perguruan tinggi menjadi terganggu dan mengalami kerugian. Informasi yang akurat, relevan dan tepat waktu merupakan dasar bagi pimpinan perguruan tinggi dalam pengambilan keputusan strategis dengan tepat, cepat dan sesuai dengan tujuan perguruan tinggi.

Informasi yang akurat, relevan dan tepat waktu ketika dibutuhkan, dihasilkan dari ketersediaan data yang ada pada perguruan tinggi. Ketersediaan data dalam jumlah yang besar dan kompleksitasnya, memerlukan penanganan terlebih dahulu, seperti pembersihan data, pemilihan data, integrasi data, transformasi data, dan lain-lain sebelum data tersebut diolah lebih lanjut. Oleh karenanya dibutuhkan cara (metode) yang tepat agar data yang diperoleh dan akan diolah lebih lanjut sesuai dengan kebutuhan perguruan tinggi. Kebutuhan informasi bagi pimpinan perguruan tinggi tentunya berbeda dengan pelaksana operasional (staff) perguruan tinggi. Kebutuhan informasi bagi pimpinan perguruan tinggi harus disajikan dalam bentuk yang mudah dipahami dan dapat ditampilkan dalam bentuk yang lebih informatif, seperti tampilan grafik, drilldown, dan lain-lain. Oleh karena itu, dibutuhkan sistem informasi yang dapat digunakan oleh pimpinan perguruan tinggi yang dalam penggunaannya tidak mengharuskan pimpinan memiliki pemahaman yang tinggi dalam bidang teknologi informasi.

Universitas Banten Jaya (UNBAJA) adalah salah satu perguruan tinggi yang berlokasi di Jl. Ciwaru Raya No. 73 Warung Pojok, Kota Serang - Banten. UNBAJA terdiri dari 11 program studi yang tersebar di 3 fakultas yaitu Fakultas Ilmu Komputer, Fakultas Teknik dan Fakultas Keguruan dan Ilmu Pendidikan. Unsur pimpinan UNBAJA terdiri atas Rektor, Wakil Rektor, Dekan, dan Kepala Biro/Lembaga yang merupakan eksekutif perguruan tinggi yang membutuhkan informasi yang akurat, relevan, dan tepat waktu. Data akademik UNBAJA berjumlah besar bersumber dari aktivitas akademik fakultas, program studi, biro/lembaga, dan unit kerja lainnya. Data-data akademik tersebut seperti data mahasiswa, nilai, kegiatan belajar mengajar, mata kuliah, dosen, dan lain sebagainya. Data akademik yang berjumlah besar tersebut membutuhkan sistem informasi yang dapat mendukung Pimpinan UNBAJA dalam pengambilan keputusan dengan cepat dan tepat terkait bidang akademik. Sampai dengan saat ini pimpinan UNBAJA menjalankan tugas-tugasnya tanpa didukung suatu sistem informasi yang dapat menyediakan informasi yang cepat, tepat dan akurat sehingga informasi-informasi yang dibutuhkan oleh pimpinan sering disajikan dalam bentuk yang tidak tepat, terlambat, tidak sesuai keinginan, atau bahkan salah informasi. Kesalahan-kesalahan tersebut sudah seharusnya diminimalisir bahkan ditiadakan. Tidak adanya sistem informasi yang dapat mendukung tugas dan fungsi pimpinan UNBAJA menjadi hambatan ketika informasi dibutuhkan dengan segera. Akhirnya pada beberapa permasalahan yang dihadapi, 
pimpinan tidak dapat mengambil keputusan dengan cepat dan tepat yang kemudian dapat berakibat pada kerugian dan kemunduran UNBAJA.

Dari uraian latar belakang di atas memberikan gambaran bahwa saat ini UNBAJA membutuhkan suatu sistem yang dapat menunjang tugas dan fungsi para pimpinan dalam membantu menyediakan informasi yang cepat, tepat dan akurat yang dapat digunakan untuk pengambilan keputusan. Sistem informasi eksekutif akademik dirancang untuk dapat memenuhi semua kebutuhan pimpinan tersebut. Dari penjelasan di atas dapat dirumuskan masalah sebagai berikut:

1. Bagaimana merancang sebuah sistem informasi eksekutif akademik dengan data yang masih tersebar di setiap fakultas dan unit kerja untuk mempermudah dan mempercepat pengolahan data menjadi informasi yang lebih lanjut untuk memenuhi kebutuhan pimpinan?

2. Bagaimana mengimplementasikan rancangan yang sudah dibuat agar mempermudah pimpinan dalam memperoleh informasi kehadiran dosen dan nilai mahasiswa sehingga informasi yang diperoleh pimpinan disajikan dalam bentuk yang tepat, sesuai keinginan dan tidak salah agar kinerja pimpinan makin meningkat?

3. Bagaimana keberlanjutan sistem yang telah dikembangkan sehingga pengambilan keputusan oleh pimpinan berdasarkan informasi yang sudah teruji implementasi sistemnya?

\section{LITERATURE REVIEW}

Banyak penelitian yang telah dilakukan sebelumnya mengenai sistem informasi eksekutif. Dalam upaya penerapan sistem informasi eksekutif di berbagai bidang sebelumnya dalam penelitian sebagai berikut:

1. Ostarisa, Wibowo dan M Taufik (2012) dalam penelitiannya menjelaskan bahwa penelitiannya tersebut menghasilkan sebuah aplikasi Sistem Informasi Eksekutif SPBU Pertamina, sistem ini mampu memberikan informasi yang dibutuhkan eksekutif PT. Pertamina dalam memantau perkembangan SPBU di Kota Surabaya secara cepat dan tepat, sistem ini juga mampu menampilkan informasi berupa grafik atau tabel maupun teks yang dapat di drilldown (melihat data yang lebih detail). Kekurangan yang ditemukan pada penelitian tersebut antara lain sistem yang dikembangkan belum dapat diakses dengan mobile dan hanya berskala di kota Surabaya saja.

2. Eka C., Manggiasih dan Yulistia (2013), menerangkan bahwa tujuan dari penelitian tersebut adalah untuk merancang serta membangun Sistem Informasi Eksekutif (SIE) berbasis website pada PT. Graha Cellular Pratama Palembang. Berdasarkan analisis dan pengembangan sistem informasi eksekutif tersebut dapat diambil kesimpulan bahwa dengan adanya sistem tersebut general manager dapat memperoleh laporan lebih cepat dan mudah dalam melakukan perkiraan order pembelian, dan dapat memantau target penjualan serta pencapaian target penjualan.

3. Anil Dawan (2011) dalam penelitiannya menjelaskan bahwa sistem informasi eksekutif yang dirancangnya digunakan untuk membantu jajaran eksekutif yang akan melakukan pencarian dan publikasi data-data akademis dan kepegawaian Fakultas

Vol.3 No.2 - Agustus 2017 
Teknik Universitas Diponegoro. Data yang dibangun sesuai dengan kebutuhan tersebut jadi mungkin saja sistem informasi eksekutif akan terus berkembang sesuai dengan kebutuhan yang ada sehingga peluang baru akan terbuka bagi pengambilan dan analisis informasi yang sebelumnya tidak tersedia pada tingkat eksekutif.

4. Penelitian oleh Cahaya Ayu Miftasari (2011) menjelaskan bahwa penelitiannya telah berhasil menjembatani Sistem Informasi Penerimaan Mahasiswa baru, Sistem Informasi Keuangan dan Sistem Informasi Akademik dengan menggunakan web service. Penelitiannya tersebut juga telah berhasil mengembangkan sistem informasi eksekutif yang mampu menampilkan aktifitas akademik dan keuangan mahasiswa yang berhubungan dengan keputusan yang akan diambil oleh pimpinan Universitas secara cepat dan tepat sehingga kinerja Unversitas menjadi lebih efektif dan efisien. Kekurangan yang ada pada penelitian ini antara lain adalah sistem dikembangkan secara off line selanjutnya akan lebih baik jika online dan informasi yang disajikan hanya sebatas fungsi akademik dan keuangan mahasiswa baru serta belum dapat memberikan informasi jumlah transaksi per angkatan per program studi.

5. Presti Wardani (2009) dalam penelitiannya menerangkan bahwa EIS dibangun berdasarkan kebutuhan dan kondisi perusahaan. PT. Adi Citra Sakti merupakan sebuah perusahaan penyedia solusi teknologi informasi yang berkomitmen memberikan pelayanan yang terbaik bagi pelanggan dan mitra bisnisnya. Meskipun sudah tidak diragukan dalam menyediakan solusi di bidang teknologi dan informasi, namun sampai saat ini pekerjaan yang berhubungan dengan administrasi pembelian masih dilakukan secara manual. Berdasarkan sistem informasi eksekutif pembelian pada PT. Adi Citra Sakti yang merupakan hasil penelitian Presti Wardani, maka dalam penelitian tersebut dapat disimpulkan bahwa: Fasilitas drill-down yang terdapat dalam sistem ini dapat membantu eksekutif dalam melihat secara lebih detail informasi yang membutuhkan perhatian khusus. Pembangunan Sistem Informasi Eksekutif Pembelian ini sudah memenuhi kebutuhan pelaporan manajemen tingkat eksekutif dalam lingkup pembelian. Kekurangan pada Sistem Informasi Eksekutif Pembelian ini adalah sistem dibangun dengan based on desktop dan menggunakan jaringan LAN sehingga terbatas pada area kantor selanjutnya sistem akan lebih baik jika dikembangkan dengan based on web supaya ketika eksekutif tidak berada di area kantor tetap dapat melihat laporan yang dibutuhkan sewaktu-waktu.

6. Penelitian yang dilakukan Deirdre Kerr (2015) menggunakan informasi tentang penggunaan strategi dalam permainan (game), diidentifikasi melalui analisis clustering dari tindakan-tindakan yang dilakukan dalam video permainan pendidikan, untuk membuat modifikasi data-driven permainan untuk mengurangi perilaku yang tidak relevan. Hasil penelitian ini menunjukkan bahwa merevisi permainan video pendidikan berdasarkan hasil data mining dapat menurunkan perilaku yang tidak relevan dalam game secara signifikan, sehingga lebih mudah untuk mengukur pemahaman siswa tentang isi yang ditargetkan. Dua revisi kecil terhadap permainan dalam penelitian ini hampir sepenuhnya menghilangkan kemampuan siswa dalam menyelesaikan tingkat (level) permainan menggunakan strategi matematika yang salah dan mengurangi strategi menebak sebanyak $42 \%$. Dua perubahan ini mengurangi persentase data game yang terdiri dari informasi yang tidak relevan dari $23 \%$ menjadi $10 \%$. Menariknya, perubahan ini juga memiliki dampak positif pada persepsi siswa pada hampir semua langkah, dengan siswa 
melaporkan persepsi yang lebih positif ketika kemampuan mereka untuk permainan sistem berkurang.

Dari enam literature review yang ada, telah banyak penelitian mengenai sistem informasi eksekutif yang diterapkan diberbagai bidang dengan memanfaatkan fasilitas drilldown, penyajian data dan informasi yang lebih informatif baik berbentuk tabel, grafik maupun angka-angka yang bergerak. Ada pula yang telah menggunakan dashboard untuk memudahkan eksekutif dalam memantau kinerja organisasi dalam satu view. Sebagian peelitian sistem informasi eksekutif tersebut telah menerapkan sistem berbasis online (web-based).

\section{PEMECAHAN MASALAH}

Dari permasalahan yang telah dijelaskan, maka pemecahan masalahnya adalah dengan membangun sebuah Sistem informasi eksekutif akademik UNBAJA. Sistem informasi eksekutif akademik UNBAJA dirancang dan diimplementasikan untuk memfasilitasi para pimpinan di lingkungan Universitas Banten Jaya untuk dapat mengambil keputusan dengan tepat, mudah dan cepat melalui penyediaan informasiinformasi yang akurat sesuai dengan kebutuhan para pimpinan. Informasi-informasi yang disediakan pada sistem informasi eksekutif akademik ini adalah informasi yang berasal dari pengolahan data akademik yaitu berupa informasi mahasiswa, informasi nilai, informasi dosen, serta informasi kehadiran dosen dalam melaksanakan perkuliahan.

Informasi-informasi yang dihasilkan oleh sistem informasi eksekutif yang dirancang ini antara lain adalah informasi yang berkaitan dengan nilai mahasiswa, sebagai contoh nilai tertinggi mahasiswa, nilai terendah mahasiswa, nilai mata kuliah dengan rata-rata terendah, nilai mata kuliah dengan rata-rata tertinggi, indeks prestasi rata-rata program studi, indeks prestasi rata-rata mata kuliah. Informasi mahasiswa, sebagai contoh mahasiswa dengan indeks prestasi terendah, indeks prestasi mahasiswa tertinggi, jumlah mahasiswa program studi tertentu dengan kriteria tertentu dan lain-lain. Informasi yang berkaitan dengan dosen, sebagai contoh dosen dengan tingkat kehadiran tertinggi, tingkat kehadiran dosen terendah, dosen yang tidak hadir pada minggu/bulan/semester berjalan, informasi dosen ijin, dan informasi dosen yang alfa.

Dengan adanya sistem informasi eksekutif akademik ini para pimpinan tidak perlu menunggu waktu lama untuk mendapatkan informasi-informasi akademik; dapat menggunakan sistem informasi tersebut dengan mudah dan dapat mengaksesnya kapan saja ketika pimpinan membutuhkan. Selain itu, informasi yang disajikan merupakan informasi yang akurat, relevan dan tepat waktu. Tampilan informasinya pun disajikan dengan bentuk yang disesuaikan dengan keinginan dan kebutuhan para pimpinan. Dalam perancangan pemodelan Sistem Informasi Eksekutif Akademik ini menggunakan UML (Unified Modeling Language) sebagai media visualisasi Sistem Informasi Eksekutif Akademik yang dibangun.

\section{a. Rancangan Umum Sistem Informasi Eksekutif Akademik.}

Sistem Informasi Eksekutif Akademik dibangun menggunakan aplikasi berbasis desktop dangan teknik jaringan berbasis client server dan bersifat multiplatform (mampu dijalankan di berbagai sistem operasi). Sistem Informasi Eksekutif 
Akademik di Universitas Banten Jaya di-Install pada komputer yang berperan sebagai web server, setelah itu sistem dapat di akses oleh user melalui browser.

Untuk melihat hubungan yang terjadi antar sistem dengan user dapat dilihat pada Gambar 4.12 berikut ini:

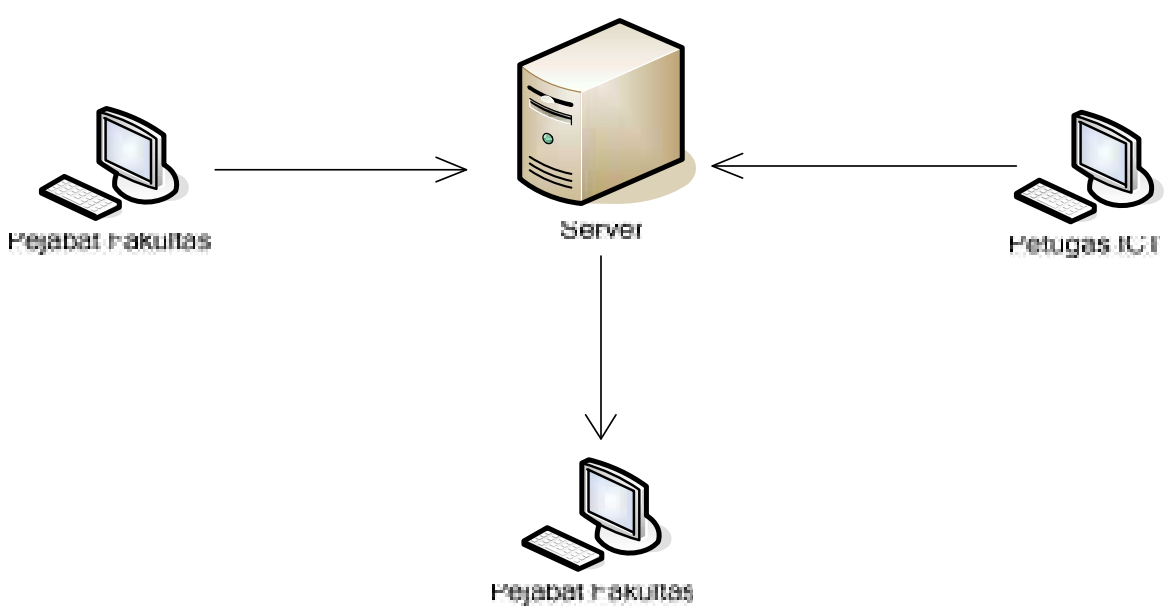

Gambar 1. Hubungan Sistem dengan User

\section{b. Rancang-Bangun Bussines Inteligence Sistem Informasi Eksekutif Akademik}

Pengembangan Bussines Inteligence (BI) Sistem Informasi Eksekutif Akademik yang dirancang pada penelitian ini adalah berbasis web, sistem dibangun untuk memudahkan user untuk memperoleh informasi mahasiswsa, nilai, dosen dan juga perkuliahan sehingga membantu proses pelaporan dan evaluasi di Universitas Banten Jaya. Untuk Proses pengolahan data transaksi mahasiswa, nilai, dosen dan perkuliahan dilakukan pada sistem informasi akademik dengan menggunakan komputer yang telah terhubung dengan jaringan berbasis client server.

Sistem Informasi Eksekutif Akademik disini menggunakan data ataupun informasi yang tersimpan pada server yang berasal dari sistem informasi akademik. Untuk lebih jelas tentang proses Sistem Informasi Eksekutif Akademik proses dapat dilihat di Gambar 4.13 di bawah ini: 


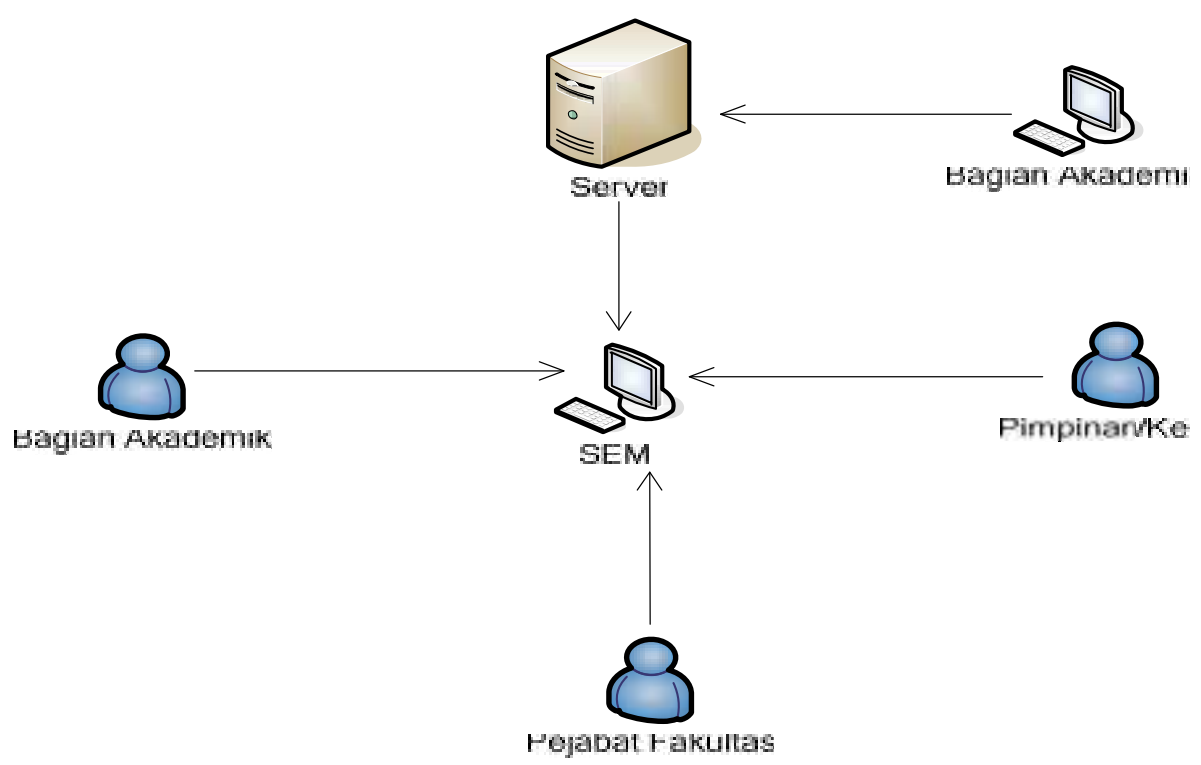

Gambar 2. Gambaran Umum Sistem Eksekutif Manajemen

\section{c. Rancangan Prosedur Sistem Informasi Eksekutif Akademik}

Perancangan pemodelan secara konseptual untuk Sistem Informasi Eksekutif Akademik ini menggunakan Unified Modelling Language (UML) sebagai media visualisasi Sistem Informasi Eksekutif Akademik yang dibangun. Use case adalah layanan (services) atau fungsi-fungsi yang disediakan oleh sistem untuk penggunanya (Henderi, 2008). Use case diagram menggambarkan fungsionalitas yang diharapkan dari sebuah sistem. yang ditekankan adalah "apa" yang diperbuat sistem, dan bukan "bagaimana". Sebuah Use case mempresentasikan sebuah interaksi antara aktor dengan sistem.

Rancangan prosedur sistem informasi eksekutif akademik yang dibangun terdapat dua aktor yaitu petugas ICT dan pimpinan, dimana pimpinan adalah pejabat fakultas maupun rektorat yang berkepentingan. Petugas ICT memiliki peran untuk mendaftarkan pimpinan sebagai user dengan melakukan login terlebih dahulu. Pimpinan yang berkepentingan diberikan hak akses dengan diberikannya user account dan password sehingga dapat melakukan login dan mengakses informasi nilai mahasiswa dan informasi kehadiran dosen seusai dengan keinginannya tanpa harus meminta bantuan kepada petugas ICT terlebih dahulu. Berikut adalah perancangan Usecase nya: 


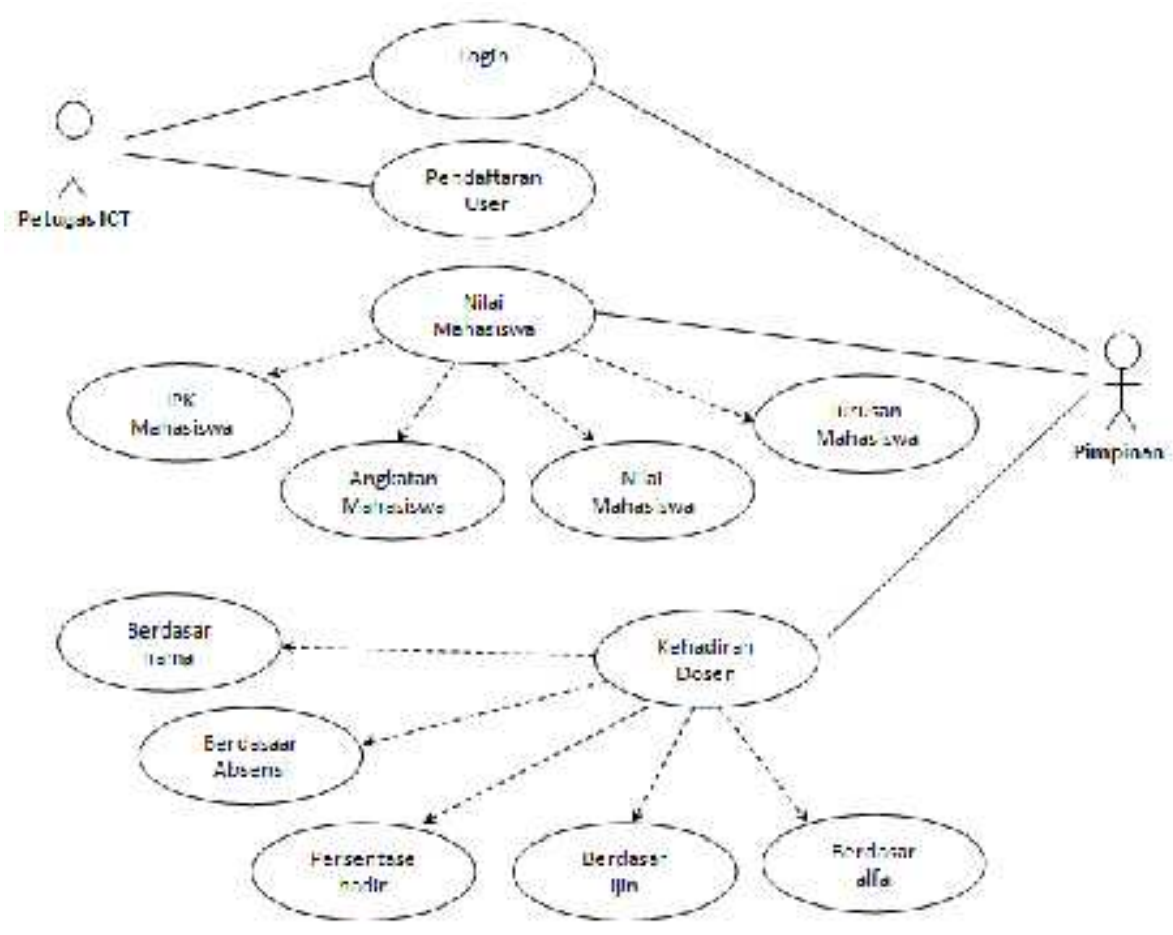

Gambar 3. Usecase Diagram Sistem Informasi Eksekutif Akademik

\section{d. Perancangan Antar Muka}

Perancangan antar muka sistem adalah desain yang dirancang untuk menerima dan melihat informasi-informasi dari pengguna sistem, rancangan input ini harus dapat memberikan kejelasan dari pemakai berupa informasi yang memiliki bussines intelligence yang cepat dan akurat. Berikut adalah rancangan-rancangan antar muka sistem informasi eksekutif akademik:

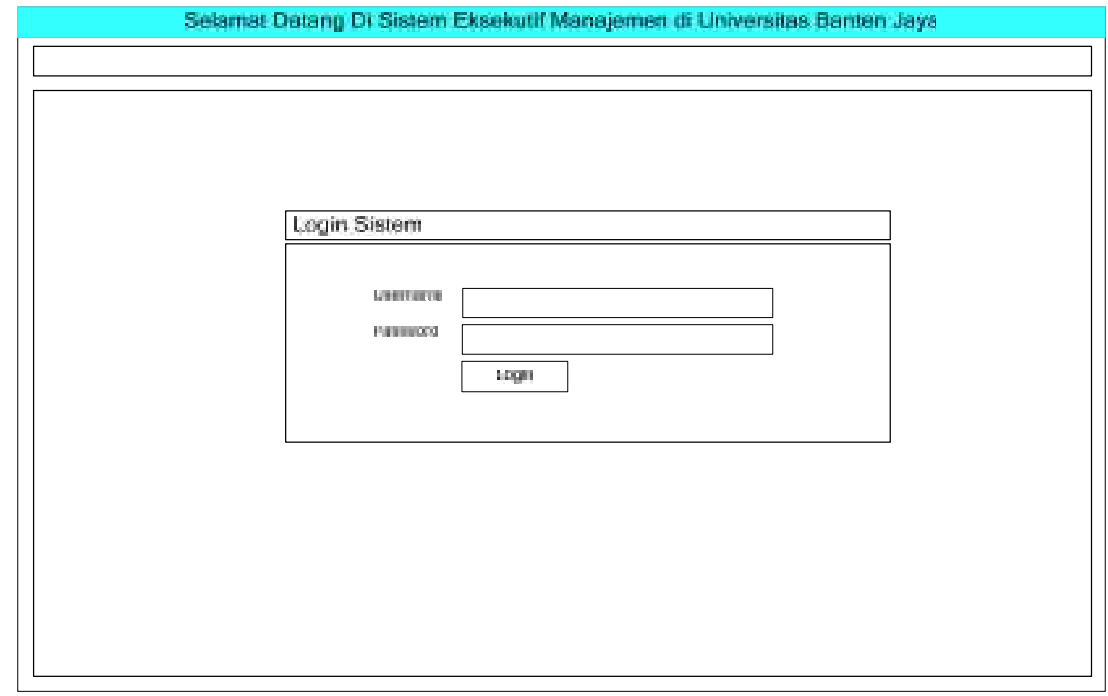

Gambar 4. Halaman Login Sistem Informasi Eksekutif Akademik

Vol.3 No.2 - Agustus 2017 
Gambar di atas merupakan gambar desain login ke Sistem Informasi Eksekutif Akademik Universitas Banten Jaya dimana user yaitu petugas ICT atau Pejabat dapat login menggunakan Username dan Password. Jika username dan password tersebut teridentifikasi oleh sistem dan sesuai maka user dapat masuk ke halaman utama sistem informasi eksekutif akademik Unbaja.

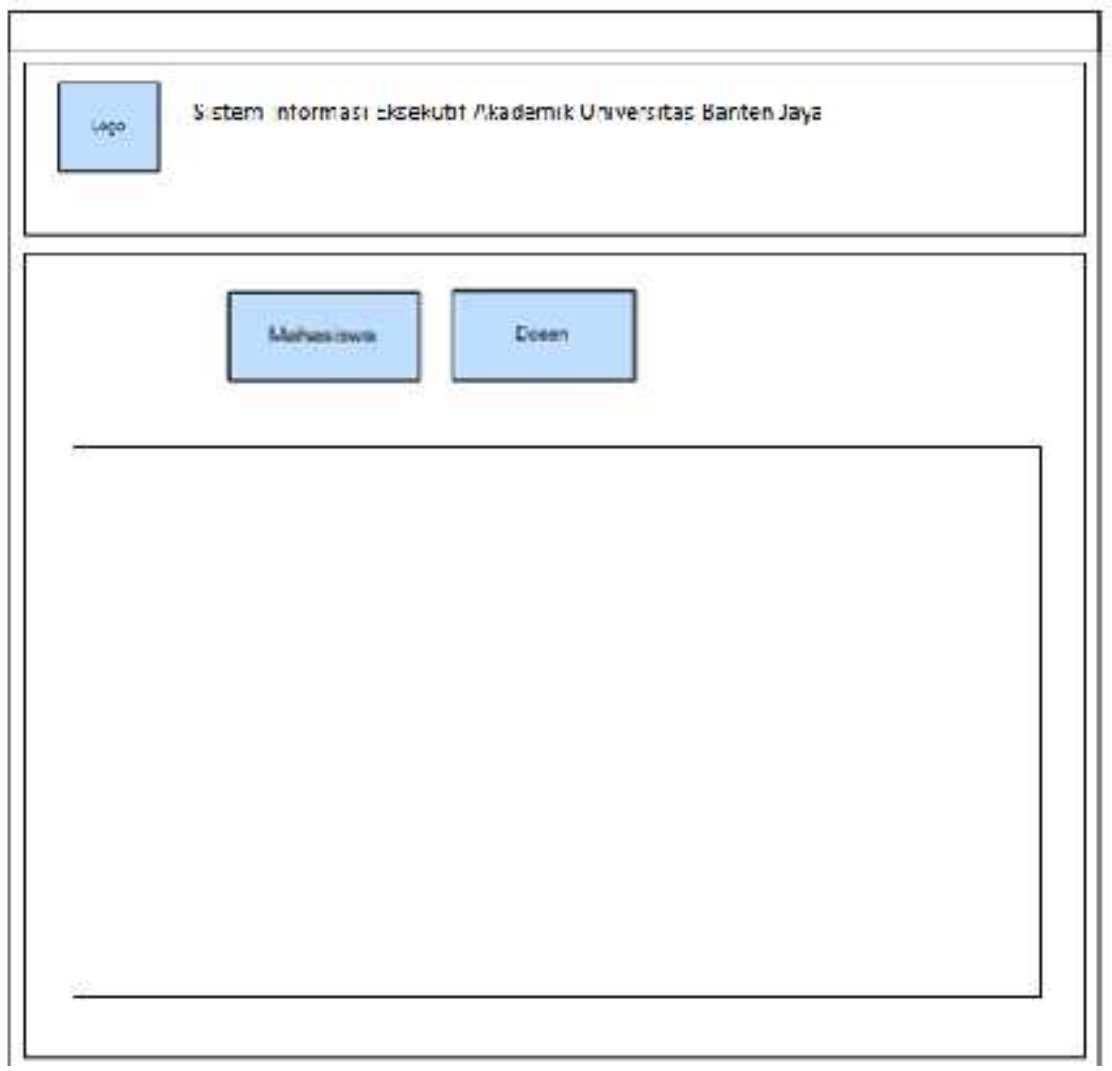

Gambar 5. Halaman Utama Sistem Informasi Eksekutif Akademik

Gambar di atas merupakan gambar desain halaman utama Sistem Informasi Eksekutif Akademik Universitas Banten Jaya dimana user yaitu petugas ICT atau Pejabat yang telah login menggunakan Username dan Password teridentifikasi oleh sistem dan sesuai maka user masuk ke halaman utama dan dapat memilih menu informasi yang diinginkan. Menu tersebut adalah mahasiswa dan dosen. 


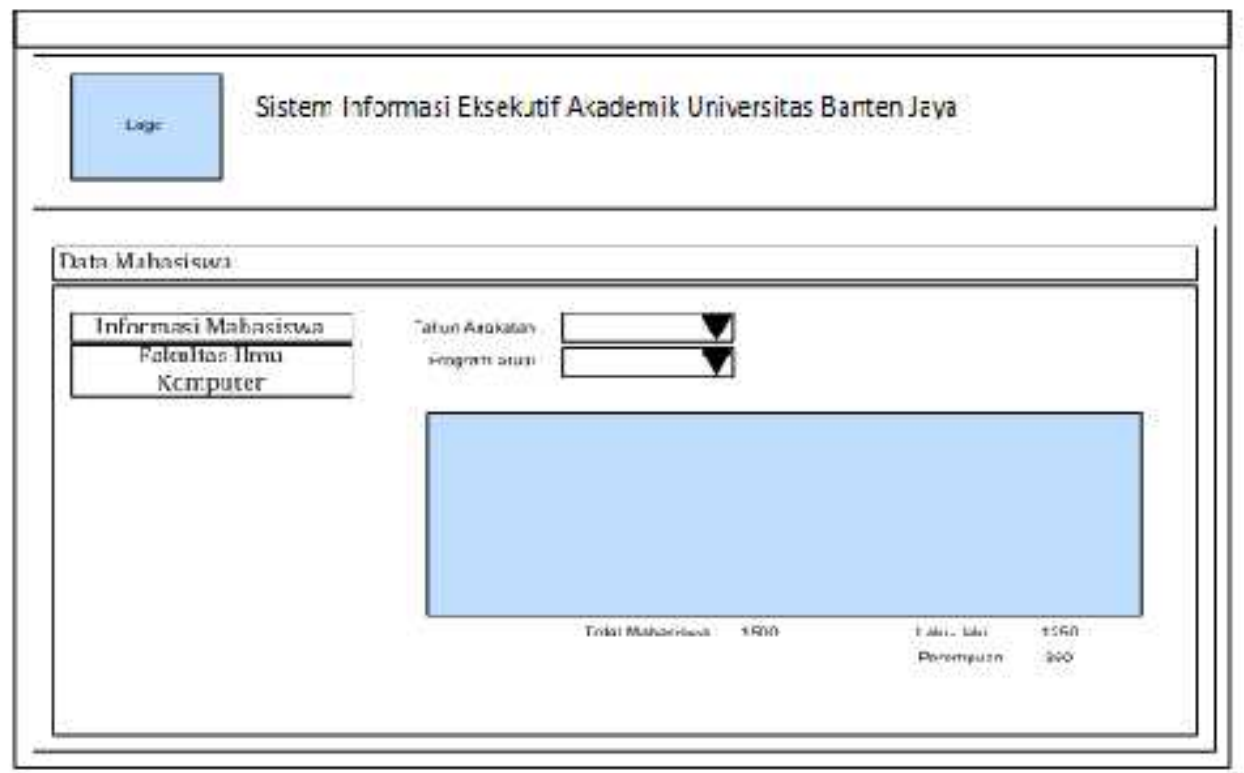

Gambar 6. Halaman Informasi Mahasiswa

Gambar di atas merupakan gambar desain halaman informasi mahasiswa dimana user yaitu petugas ICT atau Pejabat yang telah login memilih menu informasi mahasiswa maka user akan dibawa ke halaman ini. Pada halaman ini user dapat memilih jenis informasi mahasiswa yang diinginkan berdasarkan tahun angkatan dan program studi. Informasi akan ditampilkan dalam bentuk grafik untuk memudahkan pemahaman user. Pada halaman ini user pun dapat memilih informasi setiap mahasiswa yang diinginkan. 


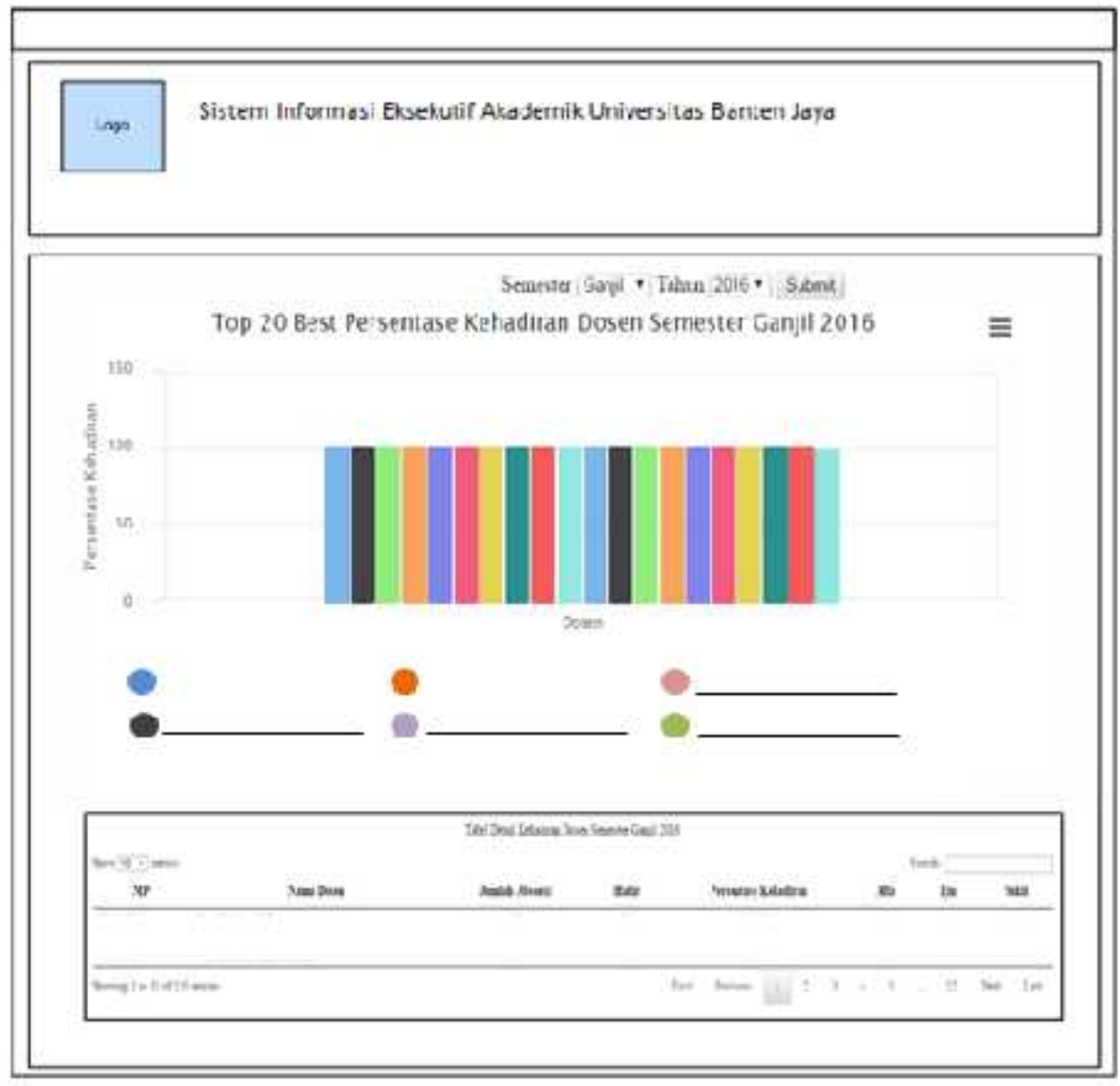

Gambar 7. Halaman Informasi Kehadiran Dosen

Gambar di atas merupakan gambar desain halaman informasi mahasiswa kehadiran dosen dimana user yaitu petugas ICT atau Pejabat yang telah login memilih menu informasi dosen maka tampilan ini akan ditampilkan oleh sistem, terdapat pilihan semester dan tahun akademik untuk memfilter dosen. Kemudian terdapat grafik yang menunjukkan kehadiran dosen berdasarkan 20 dosen dengan kehadiran terbaik. Di bawah grafik terdapat tabel dosen dimana pada tabel dosen tersebut setiap headernya dapat diklik untuk menampilkan informasi sesuai dengan keinginan. Sebagai contoh user dapat klik header nama untuk mengurutkan nama secara ascending maupun descending.

\section{IMPLEMENTASI}

Hasil perancangan sistem informasi eksekutif akademik di Universitas Banten Jaya diimplementasikan dengan menggunakan bahasa pemograman berbasis web oleh bagian akademik digunakan oleh beberapa pimpinan fakultas. Sistem informasi eksekutif akademik yang diimpementasikan dengan cara memberikan hak otoritas kepada beberapa pimpinan yang masuk ke dalam responden pada kuisioner yang dibuat dan akan dibahas di akhir penulisan laporan ini. 
Sistem informasi eksekutif akademik akan membantu pimpinan dalam memantau perkembangan perkuliahan dan juga kemahasiswaan yang nantinya akan menjadi bahan evaluasi dalam menentukan keputusan karena di dalamnya terdapat beberapa dashboard yang dapat memberikan informasi yang akurat dan juga cepat terkait kegiatan perkuliahan dan juga kemahasiswaan. Sistem informasi eksekutif akademik sendiri terdiri dari beberapa bagian penting yang akan dijelaskan sebagai berikut:

\section{a. Login Sistem}

Login sistem adalah jendela yang pertama kali akan muncul ketika sistem informasi eksekutif akademik dijalankan, merupakan bagian dari keamanan sistem dimana aplikasi hanya dapat digunakan oleh orang-orang tertentu yang sudah diberikan otoritas di dalamnya dan dalam hal ini adalah pimpinan dan juga pihak yang diberikan otoritas.

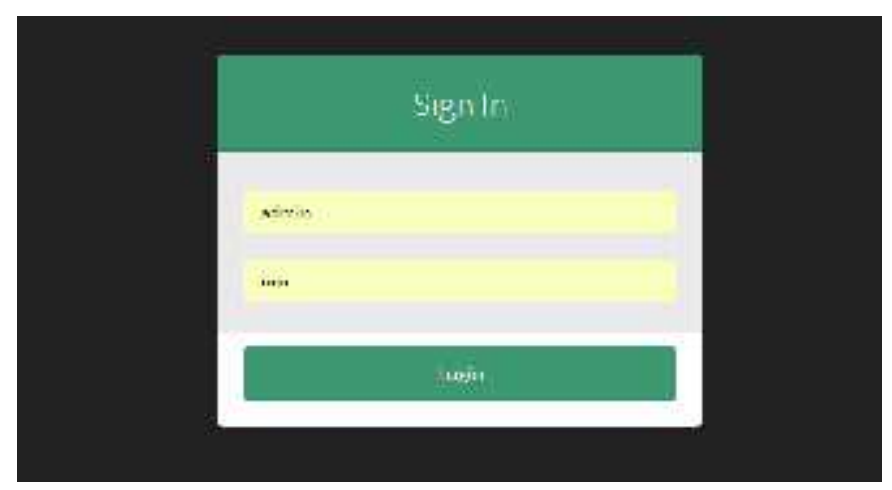

Gambar 8. Login system

\section{b. Halaman Informasi Dosen}

Pada halaman informasi dosen, pimpinan dapat melihat data statistik 20 dosen dengan kehadiran terbaik yang ditampilkan menggunakan grafik bar chart diambil dari data hasil perkuliahan dimana datanya merupakan data kehadiran mengajar dosen, pada grafik ini menunjukan 20 dosen terbaik yang kehadirannya mencapai target yaitu dengan kehadiran penuh $100 \%$.

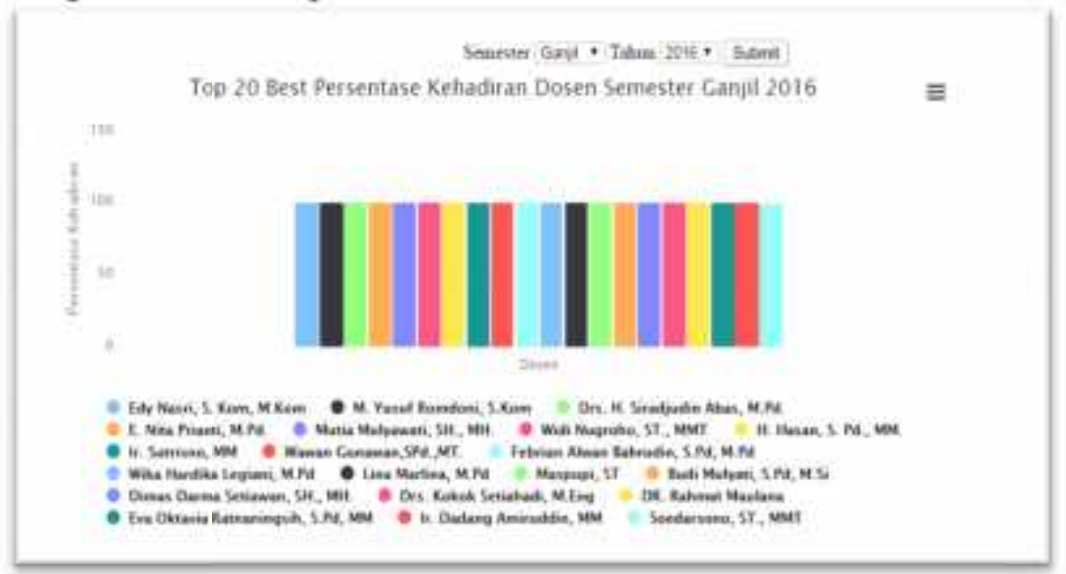

Gambar 9. Grafik statistik 20 kehadiran dosen terbaik 
Selain itu pimpinan dapat memilih informasi kehadiran dosen yang telah disediakan dalam bentuk tabel kehadiran dosen dimana pada tabel menyajikan informasi jumlah kehadiran dosen selama semester berjalan sehingga pimpinan dapat mengukur siapa saja dosen yang memiliki tingkat kehadiran yang baik, sedang dan juga rendah.

Pada tabel ini dilengkapi dengan fasilitas search untuk memudahkan pimpinan dalam melakukan pencarian dosen. Hanya dengan memberikan kata kunci pada kolom search, kolom search tersebut akan menampilkan data kehadiran dosen yang memiliki karakter awal berdasarkan kata kunci tersebut. Tabel ini dilengkapi pula dengan active header, yaitu cukup klik header tabel maka tabel akan mengurutkan baik itu ascending atau sebaliknya sesuai dengan header yang diklik.

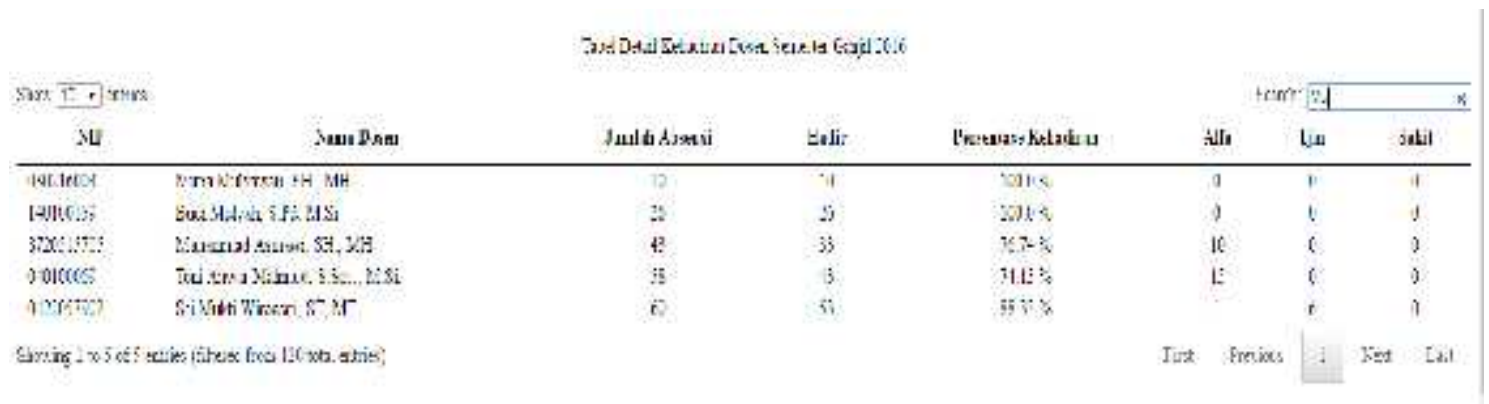

Gambar 10. Tabel kehadiran dosen

\section{c. Halaman Mahasiswa}

Pada halaman awal dashboard mahasiswa menunjukan daftar nilai mahasiswa dari seluruh fakultas yang dikemas dengan pintar dimana pada tabel dapat menunjukan jumlah seluruh nilai yang diperoleh oleh mahasiswa dari seluruh semester seperti jumlah nilai $\mathrm{A}$, jumlah nilai $\mathrm{B}$, jumlah nilai $\mathrm{C}$, nilai $\mathrm{D}$ dan nilai $\mathrm{E}$. Disamping itu juga ada IPK (Indeks Prestasi Kumulatif) keseluruhan yang ditunjukan pada akhir kolom pada setiap mahasiswa.

\begin{tabular}{|c|c|}
\hline \multicolumn{2}{|c|}{$400 \overline{10 \cdot \mathrm{crs}}$} \\
\hline MN & Yau Mehril:m \\
\hline zomi1 & 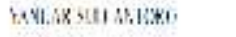 \\
\hline IMI:H & sestatu \\
\hline .12.. & tgrsiliectis \\
\hline DH.DI & د \\
\hline DI:DS| & tquxs \\
\hline Dino & Eny \\
\hline (Dit:- & 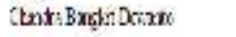 \\
\hline 1103: & littistine \\
\hline Hับข & คихาม \\
\hline Hับข" & tril; \\
\hline
\end{tabular}

\begin{tabular}{|c|c|c|c|}
\hline Andian & Jurist & & Fibil:ai \\
\hline in & Hisbliared: & & linkurats \\
\hline 1. & thathlause & & LuZnexsia \\
\hline L. & teuklffratiz & & In $x_{x y}$ \\
\hline L. & Teul.Iffme: & & Im Exast: \\
\hline L & Toblefrastis & & Ins Sxecter \\
\hline L. & Toul lefun:ls & & Ins Brepery \\
\hline L: & Tcab:Iftra:ls & & Ina Exupt: \\
\hline n & Aith latula & & Thulenich \\
\hline 1 & Piabliand: & & Inoknese \\
\hline \multirow[t]{2}{*}{ I) } & 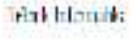 & & Inoxupere \\
\hline & & Fas: & Hetin 1 \\
\hline
\end{tabular}

\begin{tabular}{|c|c|c|c|c|c|}
\hline & & Sist: & & & \\
\hline$\Delta$ & B & $c$ & II & E & IFK \\
\hline 1 & 6 & $\xi$ & 5 & ; & $1 \%$ \\
\hline . & D) & 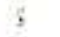 & $t$ & 1 & a.s \\
\hline$\therefore$ & 17 & ; & 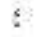 & 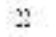 & 1.45 \\
\hline$\vdots$ & b & 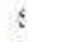 & 1 & ; & :.. \\
\hline$i$ & 35 & B & : & 9 & ‥t. \\
\hline $1-$ & 2 & ; & : & ss & 1.32 \\
\hline$\vdots$ & $!$ & $?$ & : & 23 & 1.2 \\
\hline 1 & 5 & 6 & 5 & i & $1 \%$ \\
\hline 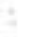 & 1. & 5 & 7 & 7 & 48 \\
\hline . & is & 7 & 4 & , & $\therefore$ \\
\hline 1 & ! & $\ldots$ & $\because i$ & As & I.s \\
\hline
\end{tabular}

Gambar 11. Tabel nilai mahasiswa

Pada gambar diatas menunjukan statistik nilai yang diperloeh setiap mahsiswa dari seluruh fakultas, dengan adanya tabel tersebut maka akan sangat membantu pihak Vol.3 No.2 - Agustus 2017 
pimpinan dari setiap fakultas untuk memantau aktifitas mahasiswa selama kuliah untuk dapat diberikan keputusan demi perkembangan mahasiswa itu sendiri dan juga fakultas.

Pada halaman dashboard mahasiswa diberikan satu fasilitas pencarian yang dapat menampilkan data nilai mahasiswa jurusan dari setiap fakultas dengan cepat dan juga akurat sehingga disebut smart filtering. Smart filtering berkerja dengan cara memilih fakultas pada kolom fakultas dan memilih jurusan pada kolom jurusan setelah itu sistem akan menampillkan daftar nilai mahasiswa perjurusan dengan cepat pada tabel dibawahnya, berikut ini tampilan dari smart filtering. Dan seperti halnya tabel dosen, tabel nilai mahasiswa dilengkapi pula dengan active header, yaitu cukup klik header tabel maka tabel akan mengurutkan baik itu ascending atau sebaliknya sesuai dengan header yang diklik.
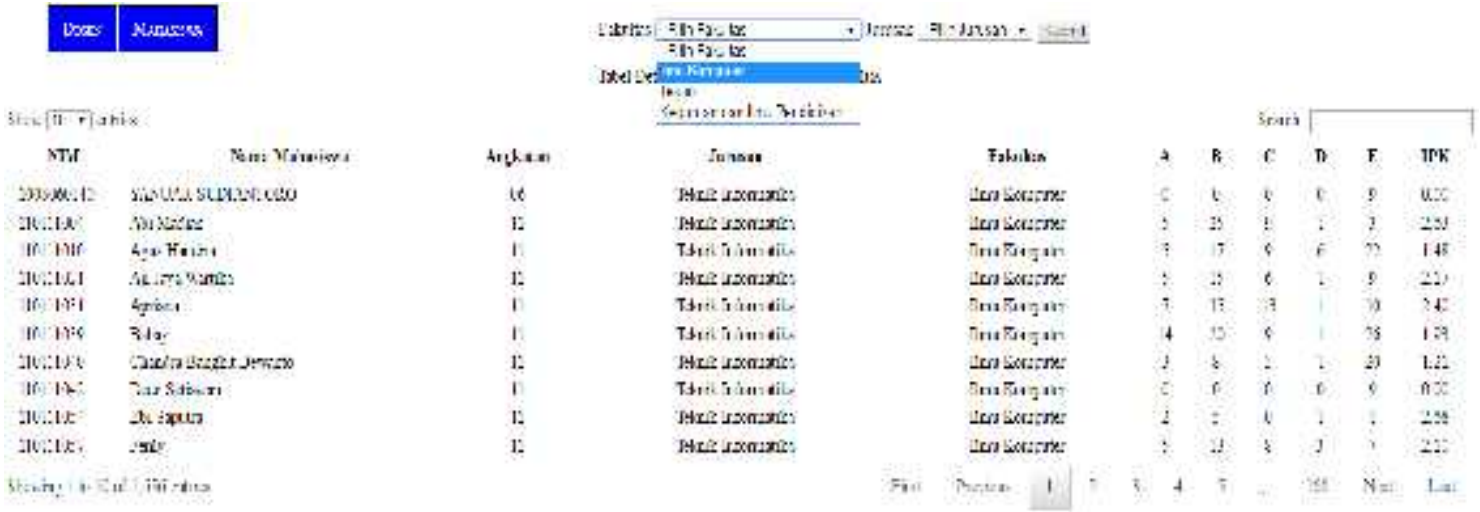

Gambar 12. Tabel nilai mahasiswa dengan smart filtering

\section{KESIMPULAN}

Setelah uraian penjelasan mengenai hasil dan pembahasan pada bab sebelumnya, maka kesimpulan yang didapat dari penelitian ini adalah sebagai berikut:

1. Pengembangan sistem informasi eksekutif akademik menggunakan data dan informasi yang terintegrasi berasal dari sistem informasi akademik yang berjalan di Universitas Banten Jaya telah memudahkan dan mempercepat pengolahan data menjadi informasi yang lebih lanjut untuk memenuhi kebutuhan informasi akademik pimpinan.

2. Penerapan sistem informasi eksekutif akademik yang dilengkapi dashboard dan smart filtering berhasil mempermudah pimpinan dalam memperoleh informasi terkait kehadiran dosen dan nilai mahasiswa sehingga informasi yang diperoleh pimpinan disajikan dalam bentuk yang tepat.

3. Penerapan sistem informasi eksekutif akademik dengan menggunakan pemrograman berbasis web dan adanya otoritas yang diberikan kepada setiap pimpinan berhasil memudahkan akses pimpinan terhadap informasi kehadiran dosen dan nilai mahasiswa kapan saja dan dimana saja. 


\section{DAFTAR PUSTAKA}

[1] Al Fatta Hanif, Analisis dan Perancangan Sistem Informasi Untuk Keunggulan Bersaing Perusahaan dan Organisasi Modern, Yogyakarta: Penerbit Andi, 2007.

[2] Dawan Anil, Sistem Informasi Eksekutif Berbasis Web Pada Fakultas Teknik Universitas Diponegoro, Semarang; Universitas Diponegoro, 2011, http://eprints.undip.ac.id/25826/

[3] Djojodibroto R. Darmanto, Tradisi Kehidupan Akademik, Yogyakarta: Galang Press, 2004.

[4] Eka C., Manggiasih dan Yulistia, Sistem Informasi Eksekuif Pembelian dan Penjualan Berbasis Website Pada PT. Graha Selullar Pratama Palembang, STMIK GI MDP, 2013.

[5] Laudon Keneth C., Laudon Jane P., Sistem Informasi Manajemen Mengelola Perusahaan Digital Edisi 10, Jakarta: Salemba Empat, 2008.

[6] Miftasari Cahaya Ayu, Pengembangan Sistem Informasi Eksekutif Menggunakan Teknologi Web Service (Studi Kasus di Fakultas Saintek UIN Sunan Kalijaga), Yogyakarta: UIN Sunan Kalijaga, 2011.

[7] Ostarisa dkk, Sistem Informasi Eksekutif Berbasis Web Pada Stasiun Pengisian Bahan Bakar Umum (SPBU) PT. Pertamina, STIKOM Surabaya, 2012.

[8] Sucipto, Konsep dan Teknik Pengembangan Sistem Berbasis Teknologi Informasi, penerbit: Dinas Pendidikan Provinsi Banten, 2011.

[9] Swain Gandharba, Object Oriented Analysis Design Through Unified Modeling Language, New Delhi: University Science Press, 20120

[10] Turban, Efraim, Decision Support and Business Intelligence Systems/ EfraimTurban, Ramesh Sharda, Dursun Delen - 9th ed. New Jersey, Pearson Education, Inc. 2011.

[11] Wahyudi Bambang, Konsep Sistem Informasi: Dari Bit Sampai Ke Database, Yogyakarta: Penerbit Andi, 2008.

[12] Wardani Presti, Sistem Informasi Eksekutif Pembelian Pada PT. Adi Citra sakti, Semarang: Universitas Dian Nuswantoro, 2009. 